\title{
Competitive Algal Community Organization in Exposed Intertidal Habitats from Central Chile
}

\author{
B. Santelices, S. Montalva and P. Oliger \\ Departamento de Biología Ambiental y de Poblaciones, Instituto de Ciencias Biológicas, Pontificia Universidad Católica de \\ Chile, Casilla 114-D, Santiago, Chile
}

\begin{abstract}
Measurements of cover in the field indicate that most of the lower intertidal waveexposed habitats of Central Chile are dominated by the colonial, non-calcareous, crustose chlorophyte Codium dimorphum. Summer bleaching of the $C$. dimorphum colonies results in reduction of cover below the $1.5 \mathrm{~m}$ intertidal level and disappearance from levels above the $1.5 \mathrm{~m}$ mark. This, in turn, results in seasonal distributional changes in mid and upper intertidal species. Field removal experiments indicate that $C$. dimorphum is able to overgrow, exclude and therefore limit the lowermost extent of most other intertidal species. Recovery of $C$. dimorphum and the course of successional events thereafter (followed during 41 months) are affected by seasonal bleaching and grazing. Herbivore exclusion experiments indicate that grazing plays a major role in the seasonal reduction of cover of C. dimorphum after initial summer bleaching of the colony. These results are discussed in view of presently accepted hypotheses on intertidal algal zonation, intertidal community structure, successional events and ecological adaptation of non-calcareous crustose algal morphologies.
\end{abstract}

\section{INTRODUCTION}

Studies thus far conducted on intertidal algal zonation in Central Chile are restricted to qualitative descriptions of species distribution and zonation patterns (Guiler, 1959a, b; Alveal, 1970, 1971; Stephenson and Stephenson, 1972; Alveal et al., 1973) with little understanding of the role of climatic and biological factors on zonation and community organization.

Presently accepted models of intertidal community dynamics (Connell, 1975; Menge and Sutherland, 1976) predict little effect of competitive interactions as structuring factors of natural communities in the presence of predators, except when species with escape mechanisms to predations or grazing are involved. Although direct experimental evidence is missing in some cases, large sizes, calcareous cell wall inclusions, chemical defenses, fugitive life histories and crustose habits all have been suggested to be potentially important antiherbivore mechanisms in benthic algae (Paine and Vadas, 1969; Paine et al., 1979; Vadas, 1979; Littler and Littler, 1980). Competitive interactions are therefore expected among these species, as Dayton (1975) found to be the case among large-sized lower intertidal kelps along the Pacific coast of North America. The pertinent literature, however, is inade- quate for us to estimate how widespread and important these exceptions could be in the organization of marine intertidal systems. Indeed, Menge and Sutherland (1976) have recognized that a key refinement to their proposed model of community organization will be an in-depth examination of the regulation of primary producers.

Mast of the space in the middle and lower intertidal levels of rocky, wave-exposed habitats in Central Chile is occupied by the colonial, non-calcareous crustose chlorophyte Codium dimorphum Svedelius. This study provides observational and experimental evidence indicating that $C$. dimorphum is one of the key organisms at these intertidal levels. We first studied the seasonal distributional changes of the $C$. dimorphum belt and the effects of these changes on the vertical distribution of other algae. Then we examined algal community changes following $C$. dimorphum removal. Finally we experimentally evaluated the role of crust integrity as a grazing escape mechanism and its importance as a factor organizing this intertidal algal community. In so doing, we describe, for the first time, successional events in intertidal habitats of temperate Pacific South America, evaluate the tenability of several general hypotheses on intertidal algal zonation (Doty, 1946; Connell, 1961; Lubchenco, 1980) and 
examine some of the ecological adaptations of noncalcareous, crustose algal morphology. So far as we are aware only Paine et al. (1979), and more recently Lubchenco and Cubit (1980) and Slocum (1980), have experimentally attempted to determine some of the ecological properties of this type of algal morphology.

\section{Study Area}

The study area at Pelancura is located $5 \mathrm{~km}$ north of Port San Antonio in Central Chile $\left(33^{\circ} 35^{\prime} \mathrm{S}\right.$ Lat.; $71^{\circ} 38^{\prime} \mathrm{W}$ Long; Fig. 1). It consists of rocky platforms receiving the full force of storm-generated waves and experiences the direct effect of onshore waves. The zonation pattern of these exposed rocky habitats is similar to the patterns described by Guiler (1959b);

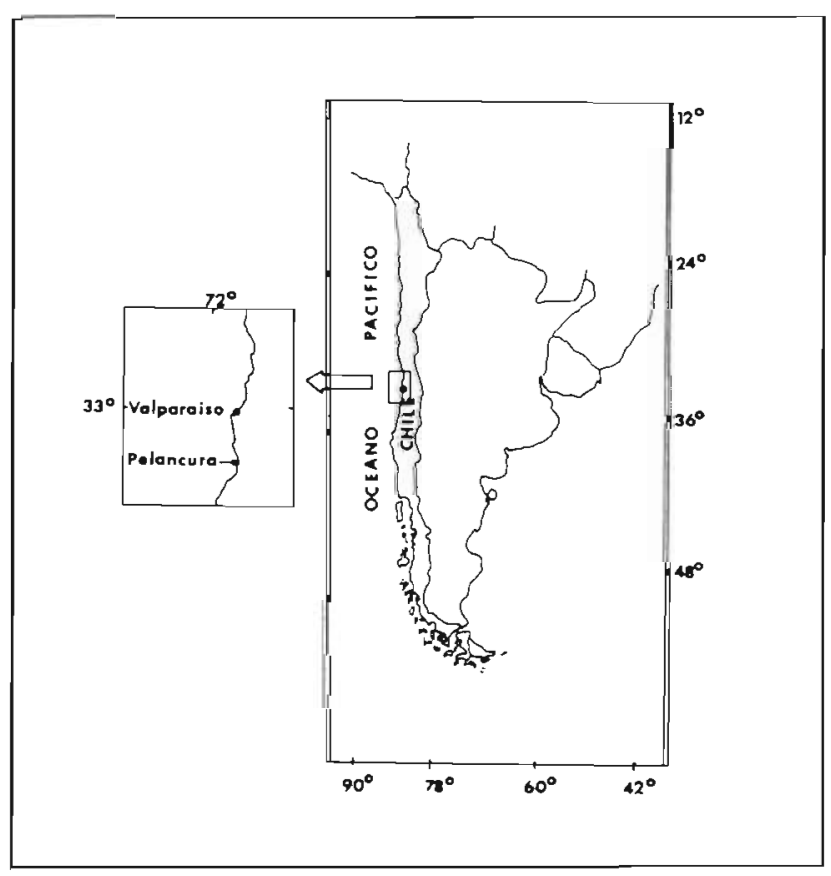

Fig. 1 Location of study sites in Central Chile

Alveal (1970) and Stephenson and Stephenson (1972) for other exposed localities in Central Chile. The sublittoral fringe is characterized by 2 species of large, kelp-like Phaeophyta (Lessonia nigrescens Bory and Durvillea antarctica [Chamisso] Hariot). A $50-100 \mathrm{~cm}$ wide zone of Codium dimorphum normally occurs immediately above the $L$. nigrescens $-D$. antarctica association while the middle and upper intertidal are characterized by pure or mixed populations of Perumytilus purpuratus (Lamarck), Chthamalus spp. and several filamentous or frondose algae such as Ulva rigida (C. Agardh) Thuret, Iridaea boryana (Setchell and Gardner) Skottsberg, Enteromorpha compressa (Lin-

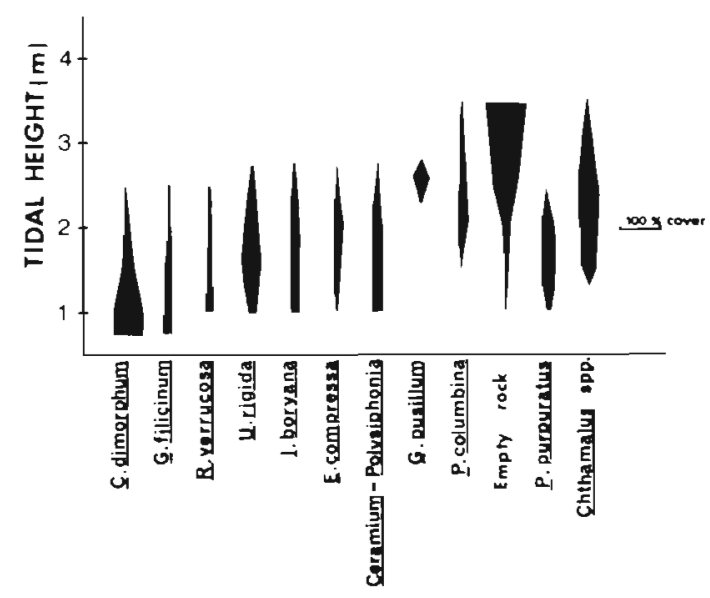

Fig. 2. Zonation pattern above the Lessonia nigrescens Durvillea antarctica belt in exposed rocky intertidal habitats of Central Chile. The zonation pattern represents average cover values of $144, \% / 4 \mathrm{~m}^{2}$ quadrats measured during a 13 month sampling program. See methods for further details

naeus) Greville and Porphyra columbina Montagne (Fig. 2). Much free primary space ('Empty rock' in Fig. 2) normally occurs at the middle and upper intertidal levels in these exposes habitats. No free primary space is normally available at the lower level of the $C$. dimorphum belt. Although Gelidium filicinum Bory is locally abundant, the C. dimorphum colonies normally extend as a continuous, flatgreen cover at this level.

\section{MATERIALS AND METHODS}

Temporal changes in space occupancy by benthic macro-algae and sessile macro-invertebrates were determined monthly with reference to tidal height. Two permanent transects ( $1 \mathrm{~m}$ wide each) extending from the upper intertidal to the Lessonia nigrescens Durvillea antarctica belt were initially established at the study site. The distance between the transects was $4 \mathrm{~m}$, their total extent $4-6 \mathrm{~m}$. Six square quadrats $\left(1 / 4 \mathrm{~m}^{2}\right)$ were systematically sampled along each transect at $0.5 \mathrm{~m}$ intervals. Vertical height of each quadrat with respect to the mean low water level (MLWL) was determined using stadia rod, inclinometer and predictions of tidal heights of the locality (Anonymous, 1976, $1977,1978,1979$ ). Each quadrat had 81 points at $5 \mathrm{~cm}$ intervals which were used to measure cover values of intertidal organisms by the point intercept method Percent cover values were averaged for those quadrats within each $0.25 \mathrm{~m}$ tidal height interval. Overall percent cover values for each species were calculated as the grand mean of all $0.25 \mathrm{~m}$ interval averages. Sampling was repeated monthly from October 1976 to October 1977. 
To test for the effects of Codium dimorphum removal on intertidal algal community structure, six $625 \mathrm{~cm}^{2}$ permanent quadrats were established in May 1976 on rocky surfaces at the level where $C$. dimorphum had the highest cover values (between 0.5 and $1.5 \mathrm{~m}$ above MLWL). The portion of the $C$. dimorphum colony inside the quadrat was manually removed and the rocky surface throughly scraped with an iron spatula and wire brushes. Colonization and species turn-over were followed monthly in these experimental plots up to October 1979. Pertinent comparisons with 6 undisturbed, previously marked control plots were performed monthly. A similarity index (Bray and Curtis, 1957) was used to measure the monthly degree of average change in the experimental plots. In general, low similarity values between the experimental plots and control plots indicate invasion of upper intertidal algae into the experimental plots. In contrast, high similarity values between the experimental plots and the $C$. dimorphum control quadrats were taken to indicate space recovery by $C$. dimorphum colonies and exclusion of other intertidal algae from the experimental plots. The Bray and Curtis' similarity index was selected to allow for pertinent comparisons with recent recolonization studies at an approximately similar latitude on the Pacific coast of North America (Murray and Littler, 1978).

As the study progressed, field evidence indicated that crust integrity reduced the susceptibility of Codium dimorphum colonies to herbivores. Crust discontinuities might allow time for the recruitment or migration of herbivores which would reduce the growth rate of the colony and slow down the recovery rates of newly vacated surfaces. To test for this hypothesis, removal experiments were repeated at the level where $C$. dimorphum had dominance using six $100 \mathrm{~cm}^{2}$ removal quadrats. Three quadrats, randomly selected, were protected from herbivores (Siphonaria lessonii Blainville, Collisella zebrina [Lesson]; Tegula atra [Lesson] and Chiton granosus Frembly) with metalic exclusion nets (cages with no roofs); the other 3 quadrats being used as control of herbivore effects on growth rates of $C$. dimorphum colonies. The area of the cleared surface covered by the regrowth ot the $C$. dimorphum colony after a given period was measured in the field using plastic sheets and planimeter and then calculated as the percent of the original surface. Measurements were performed in the 3 replicates for each experimental condition at irregular intervals during the 6 first months after $C$. dimorphum removal. To test for interactive effects of grazing with abiotic seasonal events, independent sets of experiments were started at 2 different times of the year. One was set early in the fall (May, 1979) and extended through winter and early spring (October, 1979). A second set was started early in spring (September 15, 1979 and lasted up to late summer (March, 1980).

\section{RESULTS}

\section{Temporal Changes in Vertical Distribution of Intertidal Algal Species}

Seasonal variation of Codium dimorphum includes both total vertical extent and percent cover values for a given vertical level (Fig. 3). During winter, the species can reach up to $2.5 \mathrm{~m}$ above MLWL while its upper vertical limit does not extend beyond the $1.5 \mathrm{~m}$ level during late spring and summer. In the vertical distance between 0.5 and $1.5 \mathrm{~m}$ above MLWL, C. dimorphum forms a permanent belt with percent cover values ranging from $35 \%$ in January to $62 \%$ in July (Fig. 3). Gelidium filicinum, the other permanent species at this level, normally has lower percent cover values (maximum: $20 \%$ in January).

During late spring and summer, the borders and the surface outgrows of the Codium dimorphum colonies start to bleach. Above the $1.5 \mathrm{~m}$ level much of the $C$. dimorphum belt disappears and the space is occupied by a diverse group of upper intertidal algal species such as Ulva rigida, Iridaea boryana, Ceramium sp., Polysiphonia sp. and Enteromorpha compressa. Below the $1.5 \mathrm{~m}$ level, the continuous $C$. dimorphum belt can become locally discontinuous and irregularly shaped. Individual colonies can now be recognized, many of them also with bleached borders. Iridaea boryana, Ulva rigida and Ralfsia verrucosa (Areschoug) J. Ag. are the primary space users after summer reduction of C. dimorphum below the $1.5 \mathrm{~m}$ level. The inverse relationship found between percent cover values of $C$. dimorphum and other benthic algal at different intertidal levels are shown in Fig. 4. Only the negative correlation between $C$. dimorphum and other algae cover values found $1 \mathrm{~m}$ above MLWL is statistically significant ( $\mathrm{p} \ll 0.01$ ).

The middle and upper shore levels (above $1.5 \mathrm{~m}$ MLWL) are dominated by invertebrates: Perumytilus purpuratus (Lamarck), Chthamalus cirratus Darwin and Chthamalus scabrosus Darwin; their vertical extent varies little throughout the year. Ulva rigida, Iridaea boryana, Enteromorpha compressa and Porphyra columbina are also important as primary space users (Fig. 3). Although a given thallus of any of these algal species does not persist at this level through the year, each species continuously occupies space through successive generations. Much free space is available for algal growth through most of the year (from $5 \%$ in September to $25 \%$ in December at $2 \mathrm{~m}$ above MLWL and $60 \%$ in October to $90 \%$ in January 
at $3 \mathrm{~m}$ above MLWL). This is the reason why the negative correlations between $C$. dimorphum and other algae (Fig. 4) have no statistical significance at higher intertidal levels.

In summary, the 13 months of study on space utilization patterns at the exposed intertidal rocks of Pelancura indicate that: (a) Codium dimorphum is the dominant species at the level immediately above the Lessonia nigrescens - Durvillea antarctica belt; (b) space occupied by the $C$. dimorphum colonies below the $1.5 \mathrm{~m}$ intertidal level is reduced during the summer, and the species also disappears from the levels above the $1.5 \mathrm{~m}$ mark; (c) under these circumstances, other middle upper intertidal algal species, especially
UIva rigida and Iridaea boryana, can extend their vertical distribution substantially, modifying their lower limits of intertidal algal zonation.

\section{Experimental Removal of Codium dimorphum}

The average percent cover values of several intertidal organisms found at different successional times during the 41 months of study are shown in Fig. 5. In total, 16 algal and 2 sessile invertebrate species occurred in the experimental plots; all of them are normally inhabitants of the upper intertidal. During the first months, diatoms and blue green algae invaded the
Fig. 3. Temporal changes of percent cover of the commonest intertidal species of algae and sessile invertebrates found on exposed rocky intertidal habitats of Central Chile at the Pelancura study site

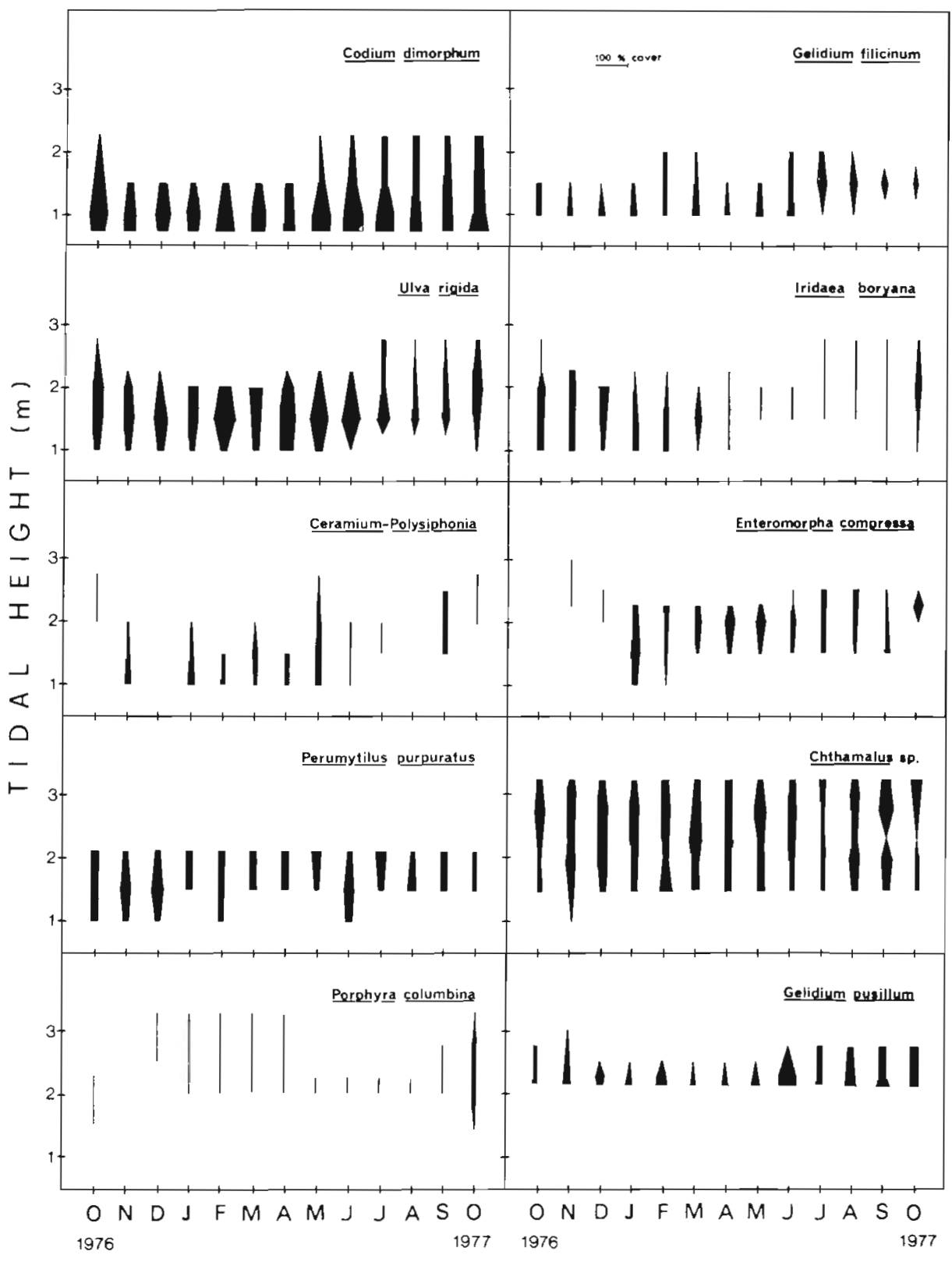




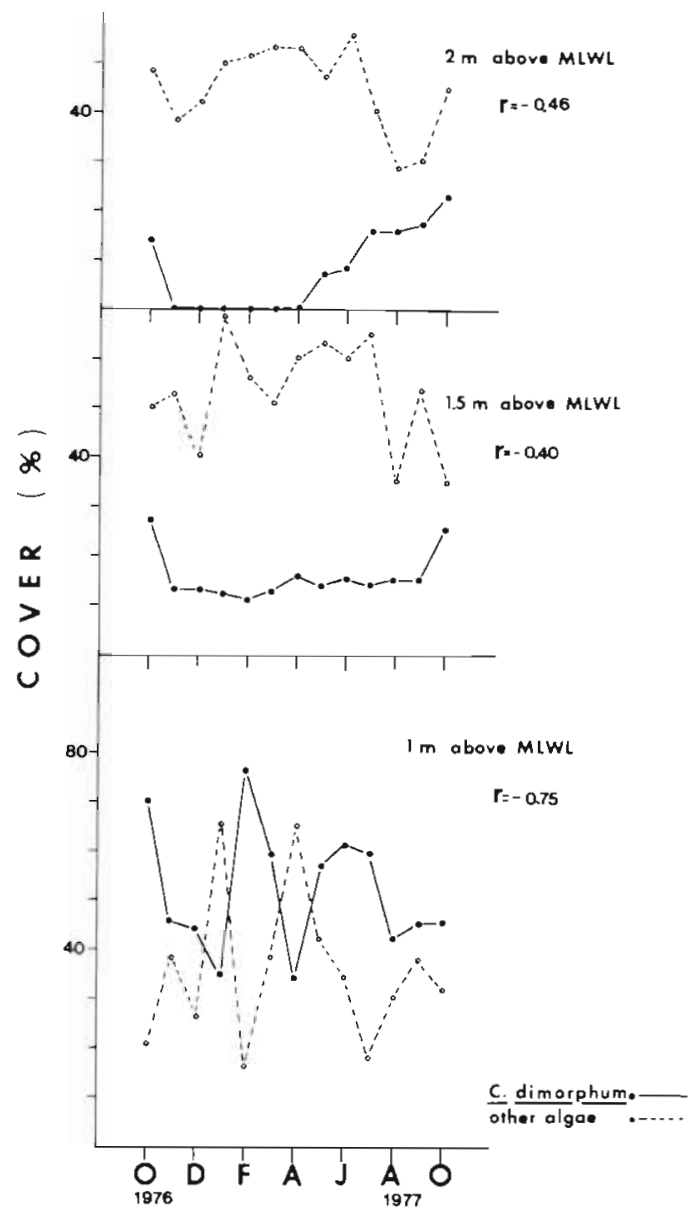

Fig 4. Codium dimorphum and other intertidal benthic algae in exposed rocky intertidal habitats of Central Chile. Correlation values equal or above 0.553 and 0.684 are significant at $5 \%$ and $1 \%$ levels respectively

quadrats covering $100 \%$ of the rocky surface. These organisms were rapidly replaced by Polysiphonia sp., Porphyra columbina, Ulva rigida and Iridaea boryana. Codium dimorphum and small individuals of Gelidium pusillum (Stack.) Le Jolis appeared as early as 8 months after clearing the $C$. dimorphum dominated space. Eleven months after removal (April, 1977) C. dimorphum had recovered an average of $5 \%$ of the rocky surface. No further changes in $C$. dimorphum cover values occurred up to October 1977. However, seasonal bleaching started affecting the colonization process at this time and new, empty primary space was produced by summer die-back of the borders of the colony of $C$. dimorphum. For November 1977, $C$. dimorphum covered on an average only $20 \%$ of the surface of the experimental plots, decreased to $10 \%$ during December, and disappeared during February 1978 (Month $N^{\circ} 21$ ).

Seasonally-affected successional events were followed for the next 20 months, at which time the experi- ments were discontinued, with no evidence of Codium dimorphum increasing its average percent cover. Only on 2 occasions during the whole study (April-October 1977 and December 1978) were the $C$. dimorphum percent cover values close to the values normally found at this level of the beach. These values, however, were later reduced by bleaching of the $C$. dimorphum colonies.

A similar conclusion is obtained when similarity values (Is) are calculated (Fig. 6) comparing the community structure of the removal plot with the lower intertidal (Codium dimorphum) control plots. The increase in average of $C$. dimorphum percent cover in the experimental plots during most of the year 1977 results in high similarity values between the experimental plots and the control plots. The summer bleaching of the $C$. dimorphum colonies during OctoberDecember 1977 affected the experimental plots more intensely and produced a major decrease in the average $C$. dimorphum percent cover. The Is values between the experimental and the control plots, therefore, decreased and reached zero similarity for January 1978. For most of 1978 the Is values remained quite low, rising again the next spring (December 1978) and then decreasing. The Is values found between March and October 1977 are essentially similar to Is values found between March and October 1979.

Growth and persistence of Codium dimorphum in the experimental plots (e.g. between April and October 1977; May-September 1978) occurs at seasons with reduced solar radiation and temperature (Fig. 6). Die back of $C$. dimorphum colonies occurs at times of increased solar radiation and temperatures and extreme low water level (e. g. November 1977 - March 1978; January 1979 - May 1979). Only on one occasion (December, 1978) did the experimental C. dimorphum removal quadrats evidence high growth rates at times of high solar radiation and increased water temperature. At that time, however, the monthly average day time extreme low tide level was above $0.35 \mathrm{~cm}$ thus allowing growth of the experimental $C$. dimorphum colonies. A similar relationship occurred in February 1976 (Fig. 4 and Anonymous, 1976). Therefore, the seasonal bleaching of $C$. dimorphum seems regulated by an interaction of at least 3 climatic factors: solar radiation, seawater temperature and day time low tide.

In summary, these removal experiments show that: (a) Within a year after removal, all upper and middle intertidal algal species and 2 of the 3 invertebrate species can occupy the newly vacated space which is dominated by extensive Codium dimorphum colonies under undisturbed conditions. (b) The recolonization pattern indicates that $C$. dimorphum can replace these species. However, recovery of $C$. dimorphum is strongly affected by bleaching of the borders of the 
colonies and even 41 months after removal, C. dimorphum was unable to recover its original value. (c) On at least 2 occasions during these 41 months (April to October 1977. December 1978), experimental $C$. dimorphum cover values were close to the undisturbed C. dimorphum values (highest Is values). Climate permitting (e. g, a delayed summer), it is likely that regrowth of $C$. dimorphum could completely cover that vacated space.

\section{Experimental Studies on Grazing}

The removal experiments indicated that free primary space is available during the first months after Codium

EXPERIMENTAL REMOVAL
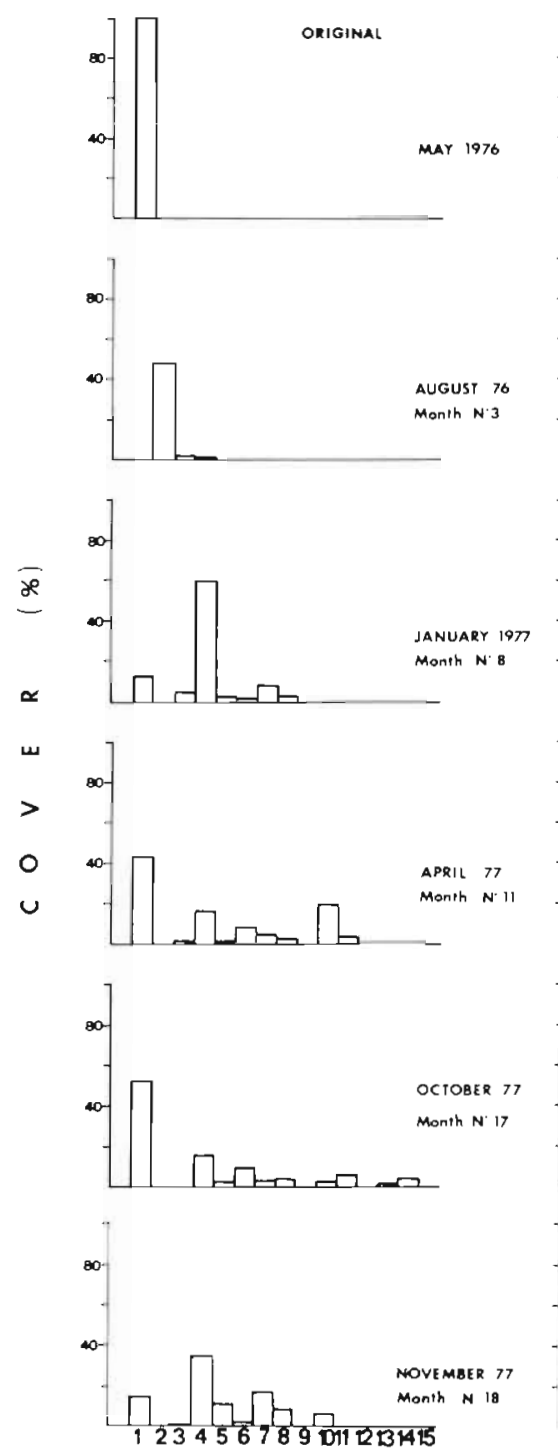

UNDISTURBED
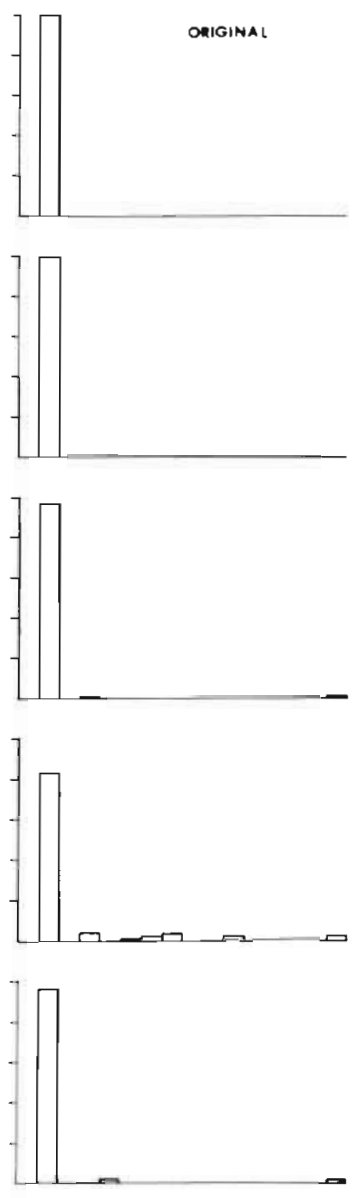

S PECIES

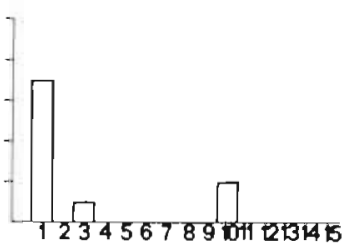

dimorphum removal (Fig. 5). Field observations imply that the average number of grazers seemingly increased after $C$. dimorphum removal, concentrating and browsing in the newly created edges of the colony. Fig. 7 compares growth rates (as percent of the originally emptied surface covered by $C$. dimorphum regrowth) on removal plots with and without herbivores exclusion, at 2 times of the year. If the growing borders of $C$. dimorphum are protected by exclusion meshes, recovery rates are faster. The effect, however, is most pronounced and statistically significant ( $p \ll 0.01$ ) in the experiment started in early spring. In that case, $C$. dimorphum recovery rate progressed fast

EXPERIMENTAL REMOVAL
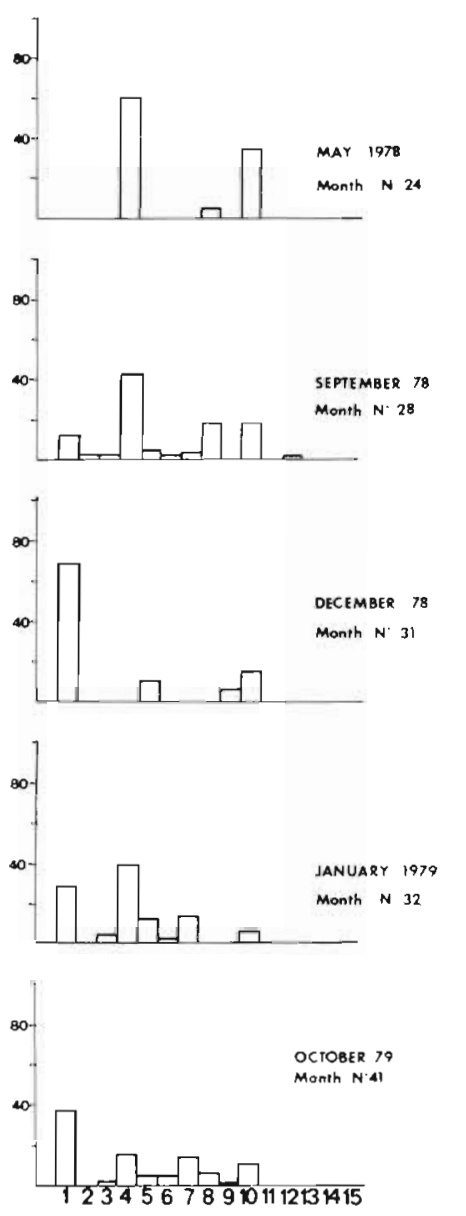

SPECIES
UNDISTURBED
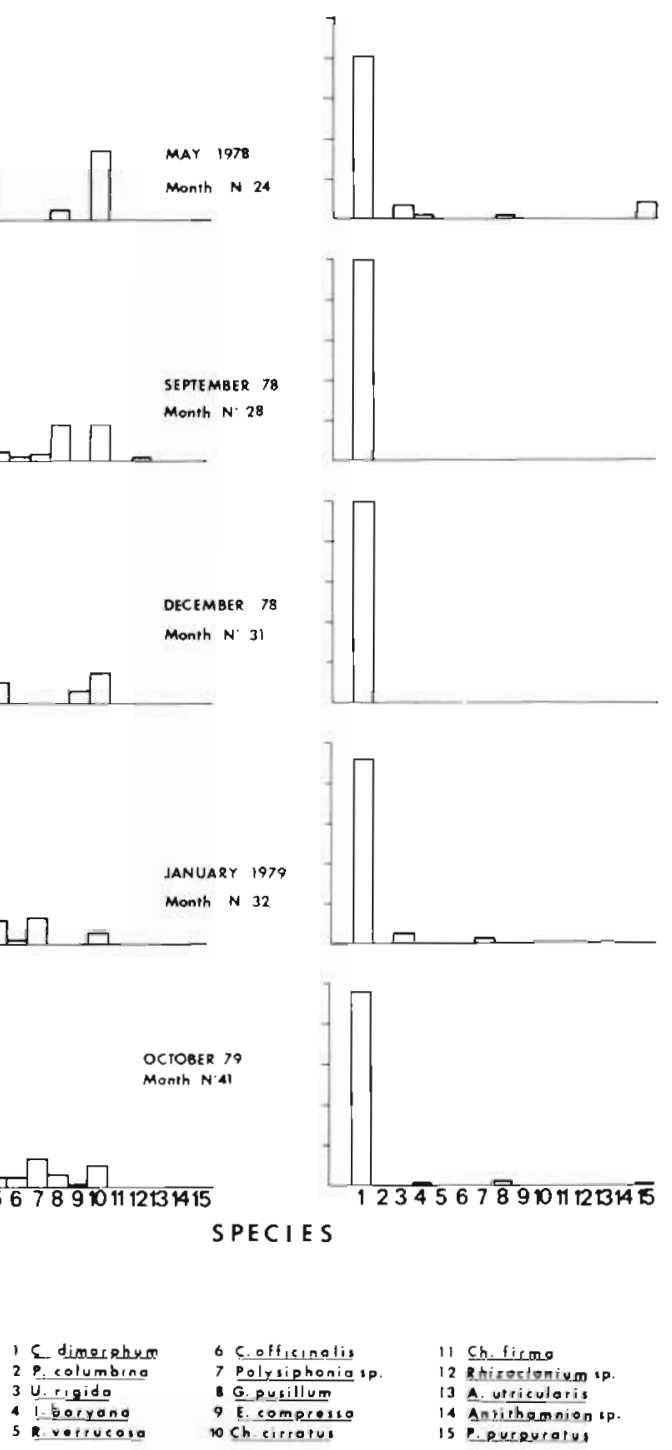

11 Ch. firmo

12 Rhiroclonivo

13 A. utricularis

14 Anrithemion

is P.purpuratus

Fig 5. Codium dimorphum removal experiments. Species turn over in experimental and control plots at selected months during the 41 month study period. Percent cover estimates the mean from six $625 \mathrm{~cm}^{2}$ quadrats for both removal and contral plots. Scytosiphon lomentaria and Bryopsis rhizophora were occasionally found in the removal plots (Months 6 and 9 respectively) 

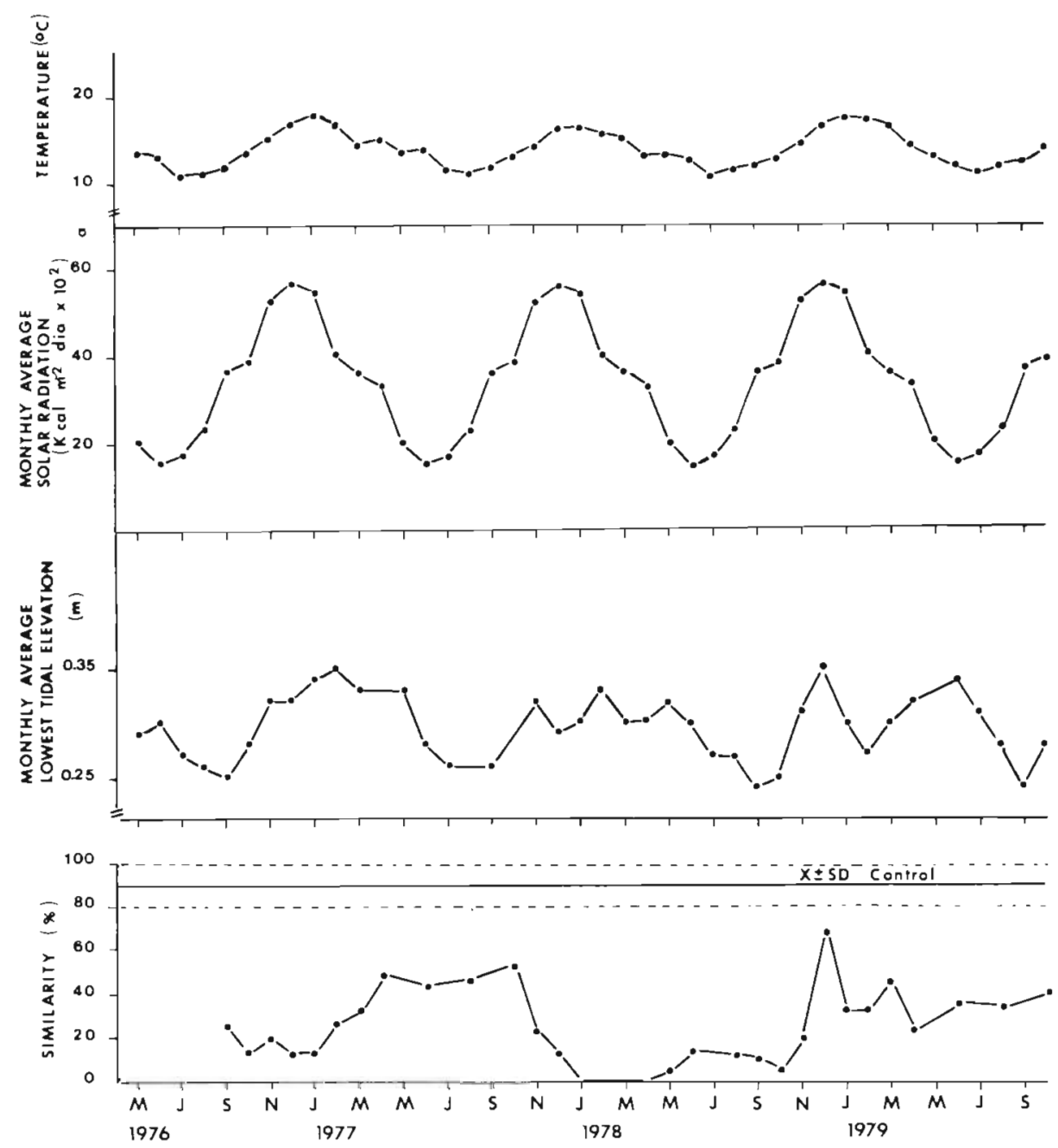

Fig. 6. Codium dimorphum removal experiments. Temporal changes in similarity index value (Is) between experimental plots (removal) and control plots. $\overline{\mathrm{X}} \pm \mathrm{S}$. D.: average Is of control plots over the whole study plus standard deviations

up to November 1979, after which time seasonal bleaching occurred. Reductions in $C$. dimorphum cover values during late summer strongly affected the quadrats without herbivore exclusion meshes and only slightly the quadrats with exclusion mesh, suggesting that an important part of the reduction of $C$. dimorphum percent cover values during summer could be due to grazing after initial bleaching of the colony borders. Field observations indicate that bleaching disrupts crust continuity creating new borders for grazer attack. Browsing from the borders of the colony reduces total $C$. dimorphum cover during this time of the year.

\section{DISCUSSION AND CONCLUSIONS}

Even though the problem of zonation patterns of intertidal organisms has been known since Lamouroux (1824) remarked on the phenomenon, much of the
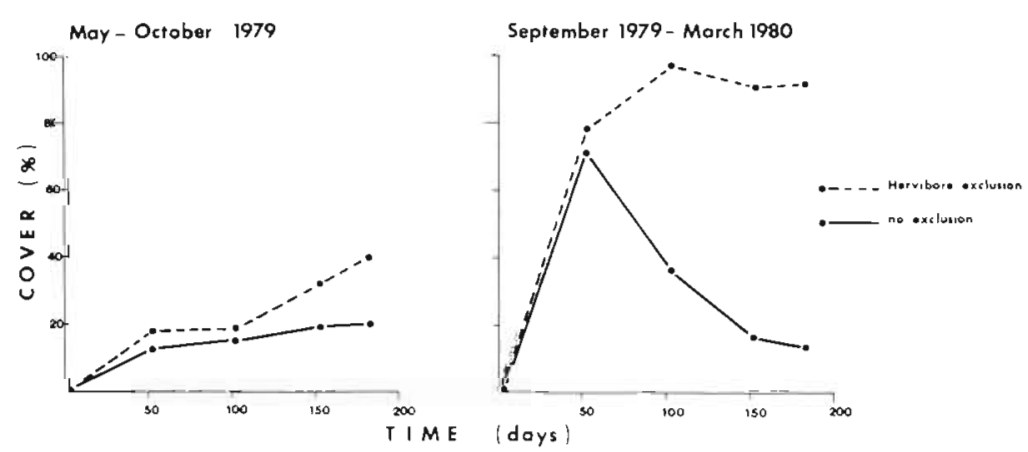

Fig. 7. Codium dimorphum. Comparative growth rates in removal experiment, protected or unprotected from grazing 
literature has been concerned with its description rather than its explanation. This is especially true for Pacific South America where most studies have been descriptive. Since the pioneer studies by Connell (1961), zonation patterns in general are recognized to be the result of the effects of physical and biological factors: lower limits of organisms are, in general, set by biological factors, while physical parameters such as desiccation are important in the determination of the upper limits of organisms. Recently, however, Lubchenko (1980) has reviewed the evidence concerning upper limits, among other reasons because Cubit (1975) had found that grazing could have a significant role in the determination of upper rocky intertidal limits of benthic algae. The results gathered in this research point to the effects of an interaction of at least 3 types of factors (climate, predation and competition) in the determination of relative importance and upper limits of Codium dimorphum in the intertidal habitats of Central Chile. During spring and summer, increased light intensity and temperatures, coupled with increased frequency of extreme day-time low tides, bleach the $C$. dimorphum colonies disrupting crust continuity and creating new borders susceptible to grazer attack. Percent cover of $C$. dimorphum is thus reduced in the lower intertidal levels of the belt and the plant completely disappears from the middle intertidal levels. During fall, winter and early spring decreased light intensity and temperature, and reduced frequency of extreme day-time low tide allows C. dimorphum growth. Its cover increases in the lower intertidal and extends as discrete, discontinuous patches, into the middle intertidal. The invasion of upper levels of the $C$. dimorphum beit by this species at this time of the year probably results from a superior competitive ability with respect to other algal species. In the same manner it dominates successional events after its removal from the low intertidal.

There are not yet enough data available to explain what determines the lower limit of the Codium dimorphum zone in Central Chile. As mentioned earlier, in exposed habitats the lower limit of the $C$. dimorphum zone coincides with the Lessonia nigrescens - Durvillea antarctica zone. Previous studies (Santelices, 1979; Santelices et al., 1980) and ongoing research point to a multiple interaction where grazing on C. dimorphum, and the effects of desiccation and predation on juveniles of $L$. nigrescens are all factors to be considered. In an analogous way, the present results also indicate that the lower limits of other frondose intertidal algae (especially Ulva rigida and Iridaea laminaroides) are determined by the upper limit of $C$. dimorphum and therefore also by a complex of several, biotic and abiotic factors.
The findings on Codium dimorphum allow an evaluation of some of the presently accepted general theory explaining organization of biological communities. Menge and Sutherland (1976) have proposed a general, simple model, critically evaluating the roles of competition and predation as structuring agents. Their model predicts little effect of competition on the determination of the importance of organisms of low trophic levels (including the primary producers), except in species with escape mechanisms. In such species, it was proposed that predation could play a major role only during recruitment, thereafter the population numbers being regulated by competition. In other words: after recruitment, populations of algal species

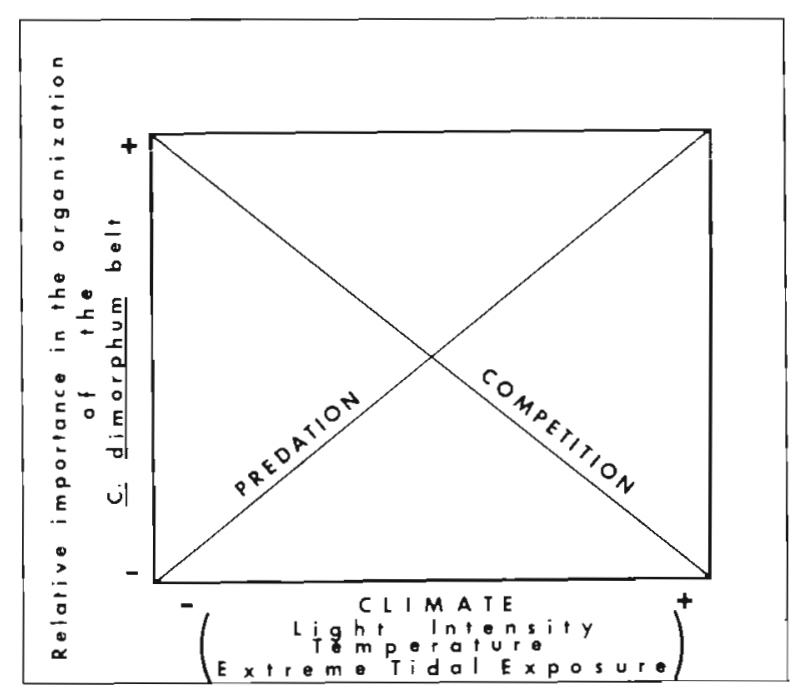

Fig. 8. Codium dimorphum. Model predicting the relative importance of climate (light intensity and extreme day time low tide), predation and competition on the growth and vertical distribution of the colonies in exposed intertidal habitats of Central Chile

with escape mechanisms should be expected to function as if they were at a 'relatively' high trophic level and not regulated by herbivores. Our results indeed indicate that $C$. dimorphum colonies should have a 'minimum size', representing the minimum able to tolerate grazing by the middle and upper intertidal grazers of Central Chile. However, from that size up, the importance of predation or competition as structuring agent would depend on climate (light intensity, temperature and extreme day time low tides) as proposed in the model shown in Fig. 8. Crustose habits have been supposed to constitute a grazing escape mechanism in benthic algae (Paine and Vadas, 1969; Paine et al., 1979; Vadas, 1979; Littler and Littler, 1980). However, in C. dimorphum crustose growth depends heavily on climate. Therefore, escape is 
incomplete, and the Menge and Sutherland (1976) model does not strictly apply to this species.

Sixteen algal species settled in the experimental plots following Codium dimorphum removal. Several of them never had been found previously at that tidal level. In essence, many other intertidal species occurring above the $C$. dimorphum level are able to fully colonize and persist in the cleared plots. Their normal occurrence is restricted to the middle and upper intertidal levels and should be interpreted as being due to overgrowth and exclusion by $C$. dimorphum rather than to the effects of physical parameters. These results emphasize the role of competitive interactions in the organization of low intertidal algal communities. So far Burrows and Lodge (1950), Dayton (1975), Lubchenko (1980), Santelices et al. (1980) and Schonbeck and Norton (1980), all have pointed to the occurrence of competitive interactions and evaluated their importance in intertidal algal communities.

As in many other studies on successional events everywhere, diatoms and blue-green algae were the earliest colonizers in all clearing experiments at Pelancura. Most previous studies predicted that the sequence of events in the process thereafter seems to be largely set by seasonality (Northcraft, 1948; Fahey and Doty, 1949; Fahey, 1953; Huvé, 1953; Guiler, 1954; Dayton, 1971; Connell, 1972; Emerson and Zedler, 1978). This is so because different organisms reproduce at different times and their reproductive propagules are more ready to colonize the newly exposed area. In the case of Codium dimorphum removal, the time of year is most important, however, in relation to the number of months available for $C$. dimorphum growth before summer bleaching starts. If the growing season for C. dimorphum is long enough to recover the newly vacated surface, the continuous crustose cover is nearly completed. If the growing season is too short, $C$. dimorphum does not complete a continuous crustose cover on the vacated surface and is strongly affected both by bleaching and subsequent grazing of the colony borders. Our results show that at least at 2 times (April-October 1977 and December 1978) during the 41 month study the $C$. dimorphum values in the experimental plots were quite similar to those in the control areas.

For the same reasons, size of disturbance patch should be important in successional events after Codium dimorphum removal. Previous studies by Moore (1939), Northcraft (1948) and Connell (1972) among others also called attention to this factor. In our case it could be predicted that the larger the size of the disturbance, the longer the time needed to recover the vacated surface, and the higher the probabilities of the whole process being affected by seasonality and predation. Size of disturbance probably has, in addition, a close relationship with the type of grazing disturbance that can be overcome by $C$. dimorphum. The size of crust discontinuities produced by small-sized grazers at the level where $C$. dimorphum occurs (Collisella zebrina, Siphonaria parasitica) never reach more than $5 \mathrm{~cm}^{2}$ in surface area and this is probably easily overgrown by $C$. dimorphum. On the other hand, $C$. dimorphum is normally absent from lower tidal levels where larger-sized grazers normally occur (e. g. large chitons such as Acanthopleura echinata (Barnes) or sea urchins such as Tetrapygus niger or Loxechinus albus (Molina). Experimental evidence is missing to test this mutually exclusive relationship, but the data on growth patterns of $C$. dimorphum allow us to predict such a relationship.

Recently, Lubchenko and Cubit (1980) and Slocum (1980), using non-calcareous algal with heteromorphic life histories, have shown that the crustose stages may be adapted to survive in areas or through times of high grazing pressure. Thus, the crustose phase in heteromorphic algae is persistent but susceptible to overgrowth, while the blade-phase is more productive but susceptible to grazing. Paine et al. (1979) further characterized ecological traits of non-calcareous, crustose heteromorphic benthic algae as phases with slow growth, relatively great longevity and persistence, possibly abetted by grazing on encrusting microflora. The life history of $C$. dimorphum is as yet unknown, but there is no evidence of heteromorphic alternation of generation in the genus Codium (Bold and Wynne, 1978). It is not surprising then that our results show similarities and differences with the previously described ecological adaptations of crustose heteromorphic algal morphologies. As in the case of these species, $C$. dimorphum can attain great age and probably has low recruitment and mortality rates. In contrast with crustose heteromorphic algae, C. dimorphum has a clear capacity to regenerate any part of the crust, has fast seasonal growth and its peripheral tissue seems at least as edible as the central area. Thus, adaptations of $C$. dimorphum include not only ecological traits of crustose heteromorphic algae but some of the adaptation of the fleshy-phase as well. Future studies on non-calcareous crustose algae should indicate whether or not ecological differences between crustose species of algae are related to differences in algal life histories.

Acknowledgements. We acknowledge with gratitude funding from Dirección de Investigación, Universidad Católica (Grant $N^{\circ} 108 / 76$ and $82 / 78$ to B. Santelices) and from International Foundation for Science, Sweden (Grant G122 to B. Santelices). We thank E. Nealler and M. E. Vera for field assistance and B. Paine and J. Sutherland for critically reading the manuscript. 


\section{LITERATURE CITED}

Alveal, K. (1970). Estudios ficoecológicos en la región de Valparaíso. Revta. Biol. mar 14:7-88

Alveal, K. (1971). El ambiente costero de Montemar y su expresión biológica. Revta. Biol. mar. 14: 85-119

Alveal, K., Romo, H., Valenzuela, J. (1973). Consideraciones ficoecológicas de las regiones de Valparaíso y Magallanes. Revta. Biol. mar. 15: 1-29

Anonymous (1976). Tablas de mareas de la costa de Chile, Instituto hidrográfico de la Armada, Chile

Anonymous (1977). Tablas de mareas de la costa de Chile, Instituto hidrográfico de la Armada, Chile

Anonymous (1978). Tablas de mareas de la costa de Chile, Instituto hidrográfico de la Armada, Chile

Anonymous (1979). Tablas de mareas de la costa de Chile, Instituto hidrográfico de la Armada, Chile

Bold, H. C., Wynne, M. J. (1978). Introduction to the algae, Prentice Hall, New Jersey

Bray, J. R., Curtis, J. T. (1957). An ordination of the upland forest communities of Southern Wisconsin. Ecol. Monogr. 27: $325-349$

Burrows, E. M., Lodge, S. M. (1950). A note of the interrelationships of Patella, Balanus and Fucus on a semiexposed coast. Rep. mar. biol. Stn Port Erin 62: 30-34

Connell, J. H. (1961). The influence of interspecific competition and other factors on the distribution of the barnacle Chthamalus stellatus. Ecology 42: 710-723

Connell, J. H. (1972). Community interaction on marine rocky intertidal shores. A. Rev. Ecol. Syst. 3: 169-192

Connell, J. H. (1975). Some mechanisms producing structure in natural communities: A model and evidence from field experiments. In: Cody, M. L., Diamond, J. M. (eds.) Ecology and evolution of natural communities. Belknap Press of Harvard University, Cambridge, pp. 460-490

Cubit, J. (1975). Interactions of seasonally changing physical factors and grazing affecting high intertidal communities on a rocky shore. Dissertation, University of Oregon, Eugene

Dayton, P. K. (1971). Competition, disturbance, and community organization: The provision and subsequent utilization of space in a rocky intertidal community. Ecol. Monogr. 41: 351-389

Dayton, P. K. (1975). Experimental evaluation of ecological dominance in a rocky intertidal community. Ecol. Monogr. 45: $137-159$

Doty, M. S. (1946). Critical tide factors that are correlated with the vertical distribution of marine algae and other organisms along the Pacific coast. Ecology 27: 315--328

Emerson, S. E., Zedler, J. B. (1978). Recolonization of intertidal algae: An experimental study. Mar. Biol. 44: 315-324

Fahey, E. M. (1953). The repopulation of intertidal transects. Rhodora 55: 102-108

Fahey, E. M., Doty, M. S. (1949). Pioneer colonization on intertidal transects (Abstract). Biol. Bull. mar. biol. Lab., Woods Hole 97: 238-239

Guiler, E. R. (1954). The recolonization of rock surfaces and the problem of succession. Pap. Proc. R. Soc. Tasm. 88: $49-66$

Guiler, E. R. (1959a). Intertidal belt-forming species on the rocky coasts of Northern Chile. Pap. Proc. R. Soc. Tasm. 93: $33-58$

Guiler, E. R. (1959b). The intertidal ecology of the Montemar area, Chile. Pap. Proc. R. Soc. Tasm. 93: 165-183

Huvé, P. (1953). Compte-rendu préliminaire d'une experience de peuplement de surfaces immergeés. Recl Trav. Stn mar. Endoume 8: 1-27

Lamouroux, J. V. F. (1824). Corallina, or a classical arrangement of flexible coralline polypidoms, Sherwoof \& Co., England

Littler, M. M., Littler, D. S. (1980). The evolution of thallus and survival strategies in benthic marine macroalgae: Field and laboratory tests of a functional form model. Am. Nat. 116: 25-44

Lubchenco, J. (1980). Algal zonation in the New England rocky intertidal community: An experimental analysis. Ecology 61: 333-344

Lubchenco, J., Cubit, J. (1980). Heteromorphic life histories of certain marine algae as adaptations to variations in herbivory. Ecology 61: 676-687

Menge, G. A., Sutherland, J. P. (1976). Species diversity gradients: Synthesis of the roles of predation, competition and temporal heterogeneity. Am. Nat. 110: 351-369

Moore, H. M. (1939). The colonization of a new rocky shore at Plymouth. J. Anim. Ecol. 8: 29-38

Murray, S. N., Littler, M. M. (1978). Patterns of algal succession in a perturbated marine intertidal community. J. Phycol. 14: 506-512

Northcraft, R. D. (1948). Marine algal colonization on the Monterey Peninsula, California. Am. J. Bot. 35: 396-404

Paine, R. T., Slocum, C. J., Duggins, D. O. (1979). Growth and longevity in the crustose red alga Petrocelis middendorffii. Mar. Biol. 51: 185-192

Paine, R. T., Vadas, R. L. (1969). Calorific values of benthic marine algae and their postulated relation to invertebrate food preference. Mar Biol. 4: 79-86

Santelices, B. (1979). Perspectivas de investigación en estructura y dinámica de comunidades intermareales rocosas de Chile Central. I. Cinturones de macroalgas. Medio Ambiente (in press)

Santelices, B., Castilla, J. C., Cancino, J., Schmiede, P. (1980) Comparative ecology of Lessonia nigrescens and Durvillea antarctica (Phaeophyta) in Central Chile. Mar. Biol 59: 119-132

Schonbeck, M. W. Norton, T A. (1980). Factors controlling the lower limits of fucoid algae on the shore. J. exp. mar. Biol. Ecol. 43: 131-150

Slocum, C. J. (1980). Differential susceptibility to grazers in two phases of an intertidal alga: Advantages of heteromorphic generations. J. exp. mar. Biol. Ecol. 46: 99-110

Stephenson, T A., Stephenson, A. (1972). Life between tidemarks on rocky shores, W. H. Freeman, San Francisco

Vadas, R. L. (1979). Seaweeds: An overview; ecological and economic importance. Experientia 35: 429-433 